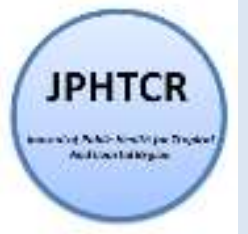

JOURNAL OF PUBLIC HEALTH FOR TROPICAL AND COASTAL REGION (JPHTCR)

Journal homepage: http:/ejournal2.undip.ac.id/index.php/jphtr/index

ISSN : 2597-4378

Research Article

\title{
Could Pictorial Health Warning Change Smoking Behavior among Teenagers? : A Cross-Sectional Study among Junior High School Students
}

\author{
Ranti Yunita Hidayah ${ }^{a}$, Novia Handayani ${ }^{b}$, Syamsulhuda B. Musthofa ${ }^{b}$

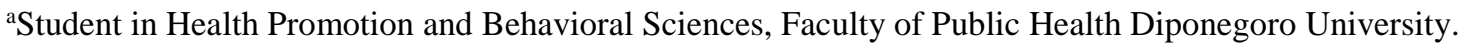 \\ Corresponding author. Email : rantiyunitahidayah22@gmail.com \\ becturer in Health Promotion and Behavioral Sciences, Faculty of Public Health Diponegoro University.
}

\begin{abstract}
Background: The Indonesian Ministry of Health has established a regulation about the inclusion of pictorial health warning and information on the packages of tobacco product since 2013. It was intended to encourage smokers to stop smoking. This study aimed to analyze the effect of pictorial health warning to teenagers' smoking behavior.

Methods: This was a quantitative study with cross sectional research design. The population was junior high school students in Semarang City. The samples were chosen from 16 junior high schools in Semarang City, representing 16 districts. Each junior high school was chosen by using probability sampling techniques. A total of 160 respondents were chosen by using simple random sampling method.

Results: The results showed that variables which have relationship with smoking behavior among teenagers were accessibility $(p=0.006)$, exposure $(p=0.039)$ and peer support $(p=0.008)$. Variables which did not have relationship with smoking behavior among teenagers were pocket money $(p=0.112)$, daily cigarette use $(p=$ $0.641)$, knowledge $(\mathrm{p}=0.535)$, attitude $(\mathrm{p}=0.759)$

Conclusion: The inclusion of pictorial health warning, especially on the packages of tobacco product encourage students as novice smokers to stop smoking.
\end{abstract}

Keywords: Pictorial Health Warning, Smoking Behavior, Teenagers, Students

Article History : Received :29-10-2019 ; Revised : 9-12-2019; Accepted: 10-12-2019

\section{Background}

There were 1.2 billion smokers in the world and 800 million of them were found in developing countries. WHO describes that there are 3 countries with the highest number of smokers in the world, namely China, India and Indonesia. Based on the data, it was predicted that in 2030 there will be 10 million people who will die and $70 \%$ of deaths will be occurred in developing countries ${ }^{1}$.

Based on the data from the Indonesian Ministry of Health, the prevalence of teenage smokers $(<15$ years old) in Indonesia increased in 2005 to $2017^{2}$. The result from National Health Indicator Survey (Sirkesnas) in 2013 showed the prevalence of children smokers 
( $<18$ years old) increased from $7.2 \%$ to $8.8 \%$ in $2016^{3}$.

The proportion of smokers in Central Java Province was 28\% in 2018. While from 2007 to 2018 the prevalence of tobacco consumption both smoking and chewing was $68.1 \%$ for men and women $2.5 \%{ }^{4}$.

The Regulation of Indonesian Ministry of Health No. 28 in 2013 about the Inclusion of Health Announcements and Health Information on Tobacco Product Packaging which explains about the use of pictorial health warnings. However, in the middle of 2017, the Ministry of Health changed the health regulation No. 28 in 2013 to health regulation No. 56 in 2017 as a result of evaluating the five pictorial health warning (PHW) which had been used previously.

Based on a case study conducted by Liem (2014) showed that mass media in the form of billboards or posters has an influence on changes in smoking behavior in adolescents. Behavior is a function of individual characteristics and their environment. While smoking is an activity or activity that is smoked then exhaled so that it will produce smoke that can be smoked by active smokers or sand ${ }^{6}$. A regulation from the government has been stipulated regarding the use of pictorial health or supporting Pictorial Health Warning for smokers in Indonesia and a place for the cigarette industry in Indonesia so that they can continue to sell their products. The Pictorial Health Warning is one of the new faces found on cigarette packs spread throughout Indonesia ${ }^{7}$

For the novice smokers, the Pictorial Health Warning on cigarette packaging can be responded in two attitudes. First is positive attitude on Pictorial Health Warning so that smokers will realize that cigarette is dangerous for themselves and others. Second is negative respond on the Pictorial Health Warning, that they do not care about the bad impact of cigarettes which they smoked everyday ${ }^{8}$

Within the school period, there are several periods which ones will create the personality of an individual, namely junior high school. Junior high school starts at the age of 12-14 years old, categorized as teenager. Teenagers tend to look for their identity and easily affected by their environment. Teenagers can be easily attracted to new things, one of those is smoking. Breaking the chain of novice smokers at the age of 12-14 years old is the right moment ${ }^{9}$

It is crucial to encourage teenage smokers to stop smoking. One of the efforts is to give an intervention, where the intervention can be a poster that contains a Pictorial Health Warning (PHW) on cigarette packages. The intervention is expected to make teenagers as novice smokers to be able to stop smoking. In addition, the intervention is also expected to be a source of literature and a contribution of scientific resources to other researchers who are also researching smoking behavior among adolescents as novice smokers.

Based on preliminary studies that have been done show that pictorial health warning has an influence for teen smokers not to try cigarettes or for teenagers who have smoked to stop smoking. Therefore this study aimed to analyze the effect of pictorial health warning to teenagers' smoking behavior.

\section{Methods}

This type of research is a quantitative using cross sectional methods. In collecting data, researchers used interview techniques with questionnaires. The population in this study was junior high school students aged 12-14 years from grades 7 to 9 in junior high schools in the Semarang City area in the academic year 2018-2019 with a total population of 65,731 junior high school students in Semarang 
City. While the sample in this study amounted to 160 respondents who met the inclusion criteria. The inclusion criteria in this study were respondents who were smoker students aged 12-14 years old who were attending junior high school in Semarang City. To be able to collect data researchers using interview techniques with the instrument is a questionnaire. Analysis of the data that has been obtained will be tested by univariate and bivariate.

In this study there are 2 variables, namely the independent variable and the dependent variable. Included in the independent variables are: predisposing factors (respondent characteristics such as grade level, allowance, number of cigarettes per day, knowledge, and attitude), enabling factors (exposure and affordability of respondents to pictorial health warning), and reinforcing factors (support of friends to stop smoking against pictorial health warning).

While the dependent variable in this study is the smoking practice of adolescents aged 12-14 years in Semarang City.

\section{Results and Discussion}

Table 1. Analysis of the effect of Pictorial Health Warning on Cigarette Packaging on Smoking Practices of Teenagers Aged 1214 Years in Semarang City.

\begin{tabular}{lcl}
\hline \multicolumn{1}{c}{ Variabel } & $\boldsymbol{\rho}_{\text {value }}$ & Description \\
\hline Grade & 0.605 & $\begin{array}{l}\text { There is } \\
\text { no effect }\end{array}$ \\
\hline Pocket money & 0.112 & $\begin{array}{l}\text { There is } \\
\text { no effect }\end{array}$ \\
\hline $\begin{array}{l}\text { Number of } \\
\text { ciggarates Per } \\
\text { day }\end{array}$ & 0.641 & $\begin{array}{l}\text { There is } \\
\text { no effect }\end{array}$ \\
\hline Knowledge & 0.535 & $\begin{array}{l}\text { There is } \\
\text { no effect } \\
\text { There is } \\
\text { no effect }\end{array}$ \\
\hline Attitude & 0.759 & $\begin{array}{l}\text { There is } \\
\text { an effect }\end{array}$ \\
\hline Affordability & 0.006 \\
\hline
\end{tabular}

\begin{tabular}{lll}
\hline Exposure & 0.039 & $\begin{array}{l}\text { There is } \\
\text { an effect }\end{array}$ \\
\hline $\begin{array}{l}\text { Friends' } \\
\text { support }\end{array}$ & 0.008 & $\begin{array}{l}\text { There is } \\
\text { an effect }\end{array}$ \\
\hline
\end{tabular}

Based on the Table 1, it can be concluded that there are three variables affected the Smoking Practices of Teenagers Aged 12-14 Years in Semarang City with $\rho_{\text {value }}<0,05$. Meanwhile there are five variables variables that have no impact on Smoking Practices of Teenagers Aged 12-14 Years in Semarang City with $\rho_{\text {value }}$ $>0,05$.

\section{The Affordability of Respondents to Pictorial Health Warning}

Based on research data show that 160 respondents who are covered with pictorial health warnings on cigarette packaging are $58.7 \%$ and the rest is about $41.3 \%$.

From the results of bivariate analysis that has been done shows that the respondents who still smoke in the affordable category $(37.2 \%)$ more than the respondents in the unreachable category $(24.2 \%)$.

The results of hypothesis testing using the Chi Square Test between the respondents 'exposure variables and the respondents' smoking practices showed the value of $\mathrm{p}=0.039<0.05$ which means, Ha was accepted Ho was rejected. So it can be concluded that there is a relationship between the respondents' exposure with the smoking practices of the respondents in 16 selected junior high schools spread throughout the Semarang City area.

Although in the research many respondents smoked affordable with pictorial health warnings. This does not guarantee the existence of factors related to the smoking practice of adolescents aged 12-14 years. Affordability is not the only factor that can influence teens to smoke. 


\section{Exposure of Respondents to Pictorial Health Warning}

From the results of research that has been done the data shows that most of the respondents were exposed by Pictorial Health Warning of cigarette packs at $66.25 \%$, while respondents were lowly exposed is $33.75 \%$ of 160 respondents.

Bivariate analysis showed that respondents who continued to smoke with the low exposure category $(32.1 \%)$ is greater than the respondents which categorized in high exposure category $(30.4 \%)$. The results of hypothesis testing using the Chi Square Test between the variables of exposure to pictorial health warnings on cigarette packs of respondents against smoking practices of respondents in 16 junior high schools in the city of Semarang showed $\mathrm{p}=<0.05$ which is 0.039 , which means that $\mathrm{Ha}$ is accepted $\mathrm{Ho}$ is rejected. So it can be conclude that there is an effect between pictorial health warning exposure with respondents smoking practices in 16 junior high schools in the city of Semarang.

In accordance with a study entitled "Hubungan Peringatan Kesehatan Bergambar di Bungkus Rokok dengan Praktik Merokok Perokok Pemula pada SMP $X$ di Kota Semarang" by Ririn Wulansari in 2016 showed a pictorial health warning effect, especially the fifth figure(smoking can cause throat cancer) and the fourth figure (smoking can cause lung cancer and chronic bronchitis) on cigarettes purchasing. Ririn Wulansari explained that the fourth figure was considered very disgusting and was the main factor influencing the interest in cigarettes purchasing. ${ }^{10}$

\section{Friends' Support to Stop Smoking Pictorial Health Warning}

In this research, the results showed that the majority of friends' support to keep smoking, amounting to $31.7 \%$ of 160 respondents.

According to bivariate analysis shows that respondents who continue to smoke categorized in does not support category $(33.3 \%)$ is greater than respondents categorized in support category $(31.7 \%)$. It can be concluded that the majority of respondents who still smoke in the support category on the pictorial health warning.

Based on hypothesis testing with the Chi Square Test between friends' support to stop smoking on pictorial health warnings on cigarette packaging on smoking practices in 16 junior high schools in the city of Semarang, it shows $\mathrm{p}=<0.05$ which is 0.008 , which means that $\mathrm{Ha}$ is accepted and Ho is rejected. So there is a relationship between friends' support to stop smoking to pictorial health warning on cigarette package on smoking practices.

In accordance with Tarwanto's research, it shows that a friend's support to stop smoking is somewhat lower, because almost of his friends are smokers. This will be a greater opportunity for respondents to continue smoking. The same thing was also found in Rochadi's (2004) study which stated that during the majority of students who smoked $(75.3 \%)$ their friends were smokers. ${ }^{11}$

\section{CONCLUSIONS}

Based on the research result, it can be concluded that respondents who have the desire to stop smoking is about $105(65.6 \%)$ and respondents who still smoke is about 55 $(34.4 \%)$ respondents. There is an effect between the respondents' affordability to get cigarettes and pictorial health warnings on cigarette packages $(\mathrm{p}=0.006)$. There is an effect between respondents' exposure to pictorial health warning on cigarette packages $(p=0.039)$. There is a relationship between respondents' friends' support to 
stop smoking and pictorial health warning on cigarette packages $(\mathrm{p}=0.008)$.

\section{REFERENCES}

1. Departemen Kesehatan tentang Kesehatan Tahun 2016. In Jakarta Selatan; 2016.

2. Kementerian Kesehatan tentang Kesehatan. Jakarta Selatan: Depkes.go.id; 2017.

3. Riskesdas. Laporan Hasil Riset Kesehatan Dasar Jawa Tengah. Jakarta: Departemen Kesehatan Republik Indonesia; 2013.

4. Riskesdas. Laporan Hasil Riset Kesehatan Dasar Jawa Tengah. Jakarta: Departemen Kesehatan Republik Indonesia; 2018.

5. Permenkes No. 28 tahun 2013. Available from: depkes.go.id

6. Suhendi Komlasari. Pengaruh Perilaku Merokok. Jakarta: Erlangga; 2006

7. Departemen Kesehatan tentang Kesehatan Tahun 2017 [Internet]. Jakarta Selatan; 2017. Available from: depkes.go.id

8. Purnomo M. Perokok Pemula di Indonesia. Perokok Pemula di Indones. 2016

9. Yuniari A. Pesan Kesehatan Bergambar di Bungkus Rokok. Yogyakarta: BioMed Central; 2017. 23-30 p.

10. Brown KS et all. Survey Methods Youth Smooking Survey Technical Report. Ottawa, Heal Canada. 2005;

11. Rochadi. Hubungan Konformitas dengan Perilaku Merokok Pada Remaja Sekolah SMUN di 5 Wilayah DKI Jakarta. Disertasi Progr Pasca Sarj Stud Ilmu Kesehat Masy Univ Indones. 2004; 